\title{
Effects of Alloying Elements on High-Temperature Oxidation and Sticking Occurring During Hot Rolling of Modified Ferritic STS430J1L Stainless Steels
}

\author{
DAE JIN HA, JONG SEOG LEE, NACK J. KIM, and SUNGHAK LEE
}

In the present study, mechanisms of sticking that occurs during hot rolling of modified STS430J1L ferritic stainless steels were investigated by using a pilot-plant-scale rolling machine, and the effects of alloying elements on sticking were analyzed by the high-temperature oxidation behavior. The hot-rolling test results indicated that the $\mathrm{Cr}$ oxide layer formed in a heating furnace was broken off and infiltrated the steel, thereby forming $\mathrm{Cr}$ oxides on the rolled steel surface. Because the surface region without oxides underwent a reduction in hardness rather than the surface region with oxides, the thickness of the surface oxide layer favorably affected the resistance to sticking. The addition of $\mathrm{Zr}, \mathrm{Cu}$, and $\mathrm{Ni}$ to the ferritic stainless steels worked in favor of the decreased sticking, but the Si addition negatively affected the resistance to sticking. In the Si-rich steel, Si oxides were continuously formed along the interfacial area between the $\mathrm{Cr}$ oxide layer and the base steel, and interrupted the formation and growth of the $\mathrm{Cr}$ oxide layer. Because the $\mathrm{Si}$ addition played a role in increasing sticking, the reduction in $\mathrm{Si}$ content was desirable for preventing sticking.

DOI: $10.1007 / \mathrm{s} 11661-011-0829-2$

(C) The Minerals, Metals \& Materials Society and ASM International 2011

\section{INTRODUCTION}

STICKING occurring during hot rolling of steels represents surface defects formed when fragments of the rolled steel are stuck to the work roll, and deteriorates surface properties of both the rolled steel and the roll. ${ }^{[1]}$ It often makes serious problems such as reduction in hot-rolling productivity, roll life, and surface quality of the rolled steel. ${ }^{[2-9]}$ However, it is difficult to solve sticking problem because sticking varies with several rolling conditions of temperature, load, speed, and lubrication and with variety of rolled steels and rolls.

Ferritic stainless steels are ferromagnetic, and have excellent cold-deformability and resistance to stress corrosion cracking, although their corrosion resistance is worse than that of austenitic stainless steels. They can also be hardened by heat treatments, and the phase transformation does not occur during hot rolling because of their stable microstructures at room and

DAE JIN HA, Post Doctoral Research Associate, is with the Center for Advanced Aerospace Materials, Pohang University of Science and Technology, Pohang 790-784, Korea. JONG SEOG LEE, Principal Researcher, is with the Research Planning Group, Technical Research Lab., POSCO, Pohang 790-785, Korea. NACK J. KIM, Professor, is with the Graduate Institute of Ferrous Technology, Pohang University of Science and Technology, and also with the Center for Advanced Aerospace Materials, Pohang University of Science and Technology. SUNGHAK LEE, Professor, is with the Center for Advanced AeroSpace Materials, Pohang University of Science and Technology, and also with the Department of Materials Science and Engineering Pohang University of Science and Technology. Contact e-mail: shlee@postech.ac.kr

Manuscript submitted February 9, 2011.

Article published online July 20, 2011 high temperatures. Although austenitic stainless steels contain 8 to $\sim 10 \mathrm{wt}$ pct of $\mathrm{Ni}$, ferritic stainless steels contain a small amount of $\mathrm{Ni}$ (less than $1 \mathrm{wt}$ pet). Ni is expensive (about ten times more expensive than any other alloying elements of stainless steels) because the extraction of $\mathrm{Ni}$ from $\mathrm{Ni}$ ores containing $\mathrm{Cu}$ requires many complicated processing steps. Recently, efforts to replace expensive austenitic stainless steels with reasonably priced ferritic stainless steels whose corrosion resistance is improved by adding alloying elements have been actively attempted.

Sticking occurs more seriously in ferritic stainless steels than in austenitic stainless steels. ${ }^{[6,7]}$ Ferritic stainless steels have excellent hardness and strength at room temperature, but their high-temperature hardness drastically decreases at about $1173 \mathrm{~K}$ to $\sim 1373 \mathrm{~K}$ $\left(900{ }^{\circ} \mathrm{C}\right.$ to $\left.1100{ }^{\circ} \mathrm{C}\right)$ where the actual hot rolling starts, which can result in sticking during hot rolling. Because high-temperature oxidation hardens the surface of the rolled steel as oxide layers or oxide particles are formed on the surface, it can favorably affect sticking. ${ }^{[10,11]}$ This finding indicates that sticking is determined by the mutual interaction of the roll and rolled steel, and that the high-temperature oxidation behavior during hot rolling plays an important role. The sticking amount is also varied with the kind of ferritic stainless steels because their alloying elements affect the high-temperature hardness and oxidation. ${ }^{[12-14]}$ Furthermore, the addition or modification of alloying elements is required to replace austenitic stainless steels, which can cause the serious sticking and consequent reduction in productivity of ferritic stainless steels. Therefore, the effects of alloying elements on sticking are essentially needed to prevent or minimize sticking and the development of 
advanced ferritic stainless steels with improved corrosion resistance, but only limited information is available.

In this study, mechanisms of sticking occurring during hot rolling of ferritic stainless steels were investigated by analyzing their high-temperature oxidation behavior. Modified STS430J1L stainless steels, which are representative ferritic stainless steels, were used for the rolled steels, and hot-rolling tests that could effectively simulate actual hot-rolling stands were conducted on these steels. Thermogravimetric analysis (TGA) tests were also conducted to investigate the high-temperature oxidation behavior. Based on the test results, mechanisms of sticking were clarified by correlating with microstructures, including oxide layer, formed on the steel surface.

\section{EXPERIMENTAL}

Five ferritic stainless steels ( $21 \mathrm{wt}$ pct $\mathrm{Cr}$-based modified STS430J1L grade) were fabricated by a vacuum induction melting method, and their chemical compositions are provided in Table I.

The basic composition is $(\leq 0.015) \mathrm{C}-(\leq 0.2) \mathrm{Si}$ $(\leq 0.3) \mathrm{Mn}-21.0 \mathrm{Cr}-0.3 \mathrm{Ni}-(\leq 0.015) \mathrm{N}-0.4 \mathrm{Cu}-0.3 \mathrm{Ti}$ (wt pct). They are referred to as steel A through E, respectively, as shown in Table I. In the ferritic stainless steels, $\mathrm{Zr}$ favorably affects the grain refinement, deformability, and weldability as a ferrite-stabilizing element. ${ }^{[15]} \mathrm{Cu}$ improves the corrosion resistance, formability, and weldability, whereas Ni improves the corrosion resistance and toughness. ${ }^{[1-18]} \mathrm{Si}$ is a good element for excellent corrosion and thermal resistance. ${ }^{[19]}$

The stainless steels were sectioned, polished, and etched in a Viellela's etchant (glycerol $45 \mathrm{~mL}+$ nitric acid $15 \mathrm{~mL}+$ hydrochloric acid $30 \mathrm{~mL}$ ) for 1 minute, and observed by an optical microscope. The oxide layer formed on the steel surface was identified by backscattered electron images in a scanning electron microscope (SEM, JSM-6330F, JEOL, Tokyo, Japan), and its average thickness was measured by an image analyzer. Hardness was measured under a 50-g load in the temperature range from room temperature to $1173 \mathrm{~K}$ $\left(900{ }^{\circ} \mathrm{C}\right)$ by a high-temperature Vickers hardness tester (FM-700, Future-Tech, Kawasaki Japan).

TGA tests were conducted with a thermogravimetric analyzer (TherMax 700, Thermo Cahn Co., Madison, WI). The TGA specimen with dimensions $15 \times 10 \times$ $5 \mathrm{~mm}$ was prepared with an electrodischarge machine, and was cleaned in acetone for 5 minutes with an ultrasonic cleaner. The test temperature and amounts of $\mathrm{O}_{2}$ and $\mathrm{SO}_{2}$ present in a heating furnace were $1533 \mathrm{~K}$ $\left(1260{ }^{\circ} \mathrm{C}\right), 3$ pct, and $100 \mathrm{ppm}$, respectively, which could simulate the heating furnace conditions in actual production lines. The specimen was heated at a rate of $50 \mathrm{~K} / \mathrm{min}$ from room temperature to $1073 \mathrm{~K}\left(800{ }^{\circ} \mathrm{C}\right)$, heated at a rate of $8.3 \mathrm{~K} / \mathrm{min}$ from $1073 \mathrm{~K}$ to $1533 \mathrm{~K}$ $\left(800{ }^{\circ} \mathrm{C}\right.$ to $\left.1260{ }^{\circ} \mathrm{C}\right)$, held at $1533 \mathrm{~K}\left(1260{ }^{\circ} \mathrm{C}\right)$ for 90 minutes, and cooled inside the thermogravimetric analyzer. The specimen weight and weight gain were automatically recorded every minute.

A pilot-plant-scale rolling machine was used for the hot-rolling test (Hitachi Metals Co., Tokyo Japan). Its major specifications and rolling conditions are shown in Table II.

The hot-rolling test was conducted on plate specimens of $120 \times 120 \times 15 \mathrm{~mm}$ in size. The specimen was heated at $1373 \mathrm{~K}\left(1100{ }^{\circ} \mathrm{C}\right)$ for 30 minutes in a heating furnace of argon gas atmosphere, and then rolled at a rolling speed of $70 \mathrm{~m} / \mathrm{min}$. Two rolling passes were performed, and the reduction ratios were 33.3 pct and $40 \mathrm{pct}$ in the first and second passes, respectively. Before and after the rolling test, the rolled specimens were sectioned, polished, and etched in a Viellela's etchant, and their cross-sectional area near the surface was observed by an SEM.

\section{RESULTS}

\section{A. Microstructure and Hardness of Ferritic Stainless Steels}

Optical micrographs of the five ferritic stainless steels are shown in Figures 1(a) through (e). Their grain size is about 130 to $\sim 140 \mu \mathrm{m}$, and their microstructure comprised ferrite, with a small amount of etch pits.

Table III shows the room- and high-temperature hardness test results of the steels.

Table II. Main Specifications of the Pilot-Plant-Scale Rolling Machine and Hot-Rolling Test Conditions

\begin{tabular}{ll}
\hline Classification & \multicolumn{1}{c}{ Specification } \\
\hline Roll material & cast iron roll \\
Mating material & modified STS 430J1L \\
Rolling force & $279 \sim 378$ ton (average: 330 ton) \\
Roll diameter & $720 \mathrm{~mm}$ \\
Rolling temperature & $1373 \mathrm{~K}\left(1100{ }^{\circ} \mathrm{C}\right)$ \\
Rolling speed & $70 \mathrm{~m} / \mathrm{min}$ \\
Plate thickness in first & $15 \mathrm{~mm} \rightarrow 10 \mathrm{~mm}$ (reduction \\
$\quad$ rolling pass & ratio; $33.3 \mathrm{pct}$ ) \\
Plate thickness in second & $10 \mathrm{~mm} \rightarrow 6 \mathrm{~mm}$ (reduction \\
$\quad$ rolling pass & ratio; $40 \mathrm{pct}$ ) \\
\hline
\end{tabular}

Table I. Chemical Composition of the 21 wt pet Cr-Based Modified STS 430J1L Grade Stainless Steels (Weight Percent)

\begin{tabular}{lcccccccccc}
\hline Steel & $\mathrm{C}$ & $\mathrm{Si}$ & $\mathrm{Mn}$ & $\mathrm{Cr}$ & $\mathrm{Ni}$ & $\mathrm{N}$ & $\mathrm{Cu}$ & $\mathrm{Ti}$ & $\mathrm{Zr}$ & $\mathrm{Nb}$ \\
\hline $\mathrm{A}$ & $\leq 0.015$ & $\leq 0.2$ & $\leq 0.3$ & 21.0 & 0.3 & $\leq 0.015$ & 0.4 & 0.3 & - & - \\
$\mathrm{B}$ & $\leq 0.015$ & $\leq 0.2$ & $\leq 0.3$ & 21.0 & - & $\leq 0.015$ & - & 0.3 & 0.02 & - \\
$\mathrm{C}$ & $\leq 0.015$ & $\leq 0.2$ & $\leq 0.3$ & 21.0 & - & $\leq 0.015$ & 0.4 & 0.3 & 0.02 & - \\
$\mathrm{D}$ & $\leq 0.015$ & $\leq 0.2$ & $\leq 0.3$ & 21.0 & 0.3 & $\leq 0.015$ & 0.4 & 0.3 & 0.02 & - \\
$\mathrm{E}$ & $\leq 0.015$ & 0.5 & $\leq 0.3$ & 21.0 & 0.3 & $\leq 0.015$ & 0.4 & 0.3 & - \\
\hline
\end{tabular}



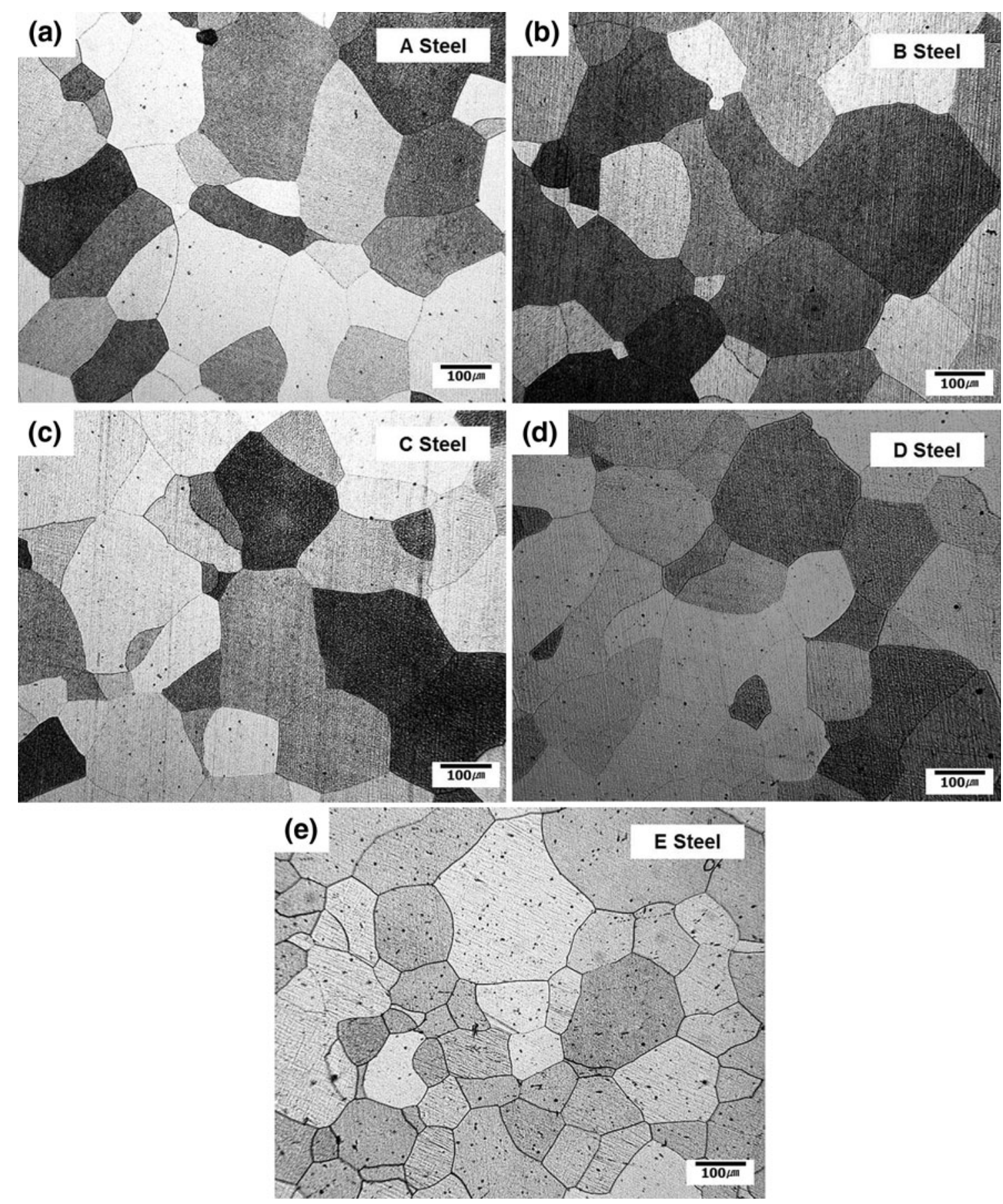

Fig. 1-Optical micrographs of the modified STS430J1L ferritic stainless steels: $(a) \mathrm{A},(b) \mathrm{B},(c) \mathrm{C},(d) \mathrm{D}$, and $(e)$ E steels. Etched by a Viellela's etchant for the stainless steels.

The room-temperature hardness ranges from 150 VHN to $165 \mathrm{VHN}$, and the A, D, and E steels are harder than the $\mathrm{B}$ and $\mathrm{C}$ steels. The hardness continuously decreases with increasing test temperature. The hardness of the A, D, and E steels drops seriously with increasing test temperature, and becomes lower than that of the $\mathrm{B}$ and $\mathrm{C}$ steels, although the hardness difference between the steels tends to decrease as the test temperature increases. At $1173 \mathrm{~K}\left(900{ }^{\circ} \mathrm{C}\right)$, the hardness is highest in the B steel, and decreases in the order of the
C, D, E, and A steels. Because the overall hightemperature hardness trend is similar in all the steels, it is expected that the variation in high-temperature hardness would hardly affect sticking. ${ }^{[12,20]}$

\section{B. High-Temperature Oxidation Behavior}

The formation behavior of high-temperature oxides formed during hot rolling was investigated by TGA, and the results are shown in Figure 2. The weight gain 
Table III. Room-and High-Temperature Hardness Results of the 21 wt pet Cr-Based Modified STS 430J1L Steels (unit: VHN)

\begin{tabular}{|c|c|c|c|c|c|}
\hline Test Temperature $\left[\mathrm{K}\left({ }^{\circ} \mathrm{C}\right)\right]$ & A Steel & B Steel & C Steel & D Steel & E Steel \\
\hline $298(25)$ & $159.2 \pm 3.3$ & $149.5 \pm 0.7$ & $148.6 \pm 2.0$ & $160.4 \pm 2.2$ & $164.5 \pm 1.4$ \\
\hline $573(300)$ & $112.0 \pm 1.5$ & $105.2 \pm 1.9$ & $105.4 \pm 1.0$ & $106.0 \pm 1.4$ & $134.5 \pm 1.2$ \\
\hline $673(400)$ & $98.1 \pm 0.9$ & $96.6 \pm 0.8$ & $95.4 \pm 0.7$ & $97.3 \pm 0.8$ & $117.4 \pm 1.1$ \\
\hline $773(500)$ & $90.9 \pm 0.8$ & $90.4 \pm 1.3$ & $88.5 \pm 0.9$ & $88.7 \pm 2.3$ & $103.8 \pm 1.3$ \\
\hline $873(600)$ & $70.2 \pm 0.8$ & $64.4 \pm 1.3$ & $70.0 \pm 1.7$ & $61.8 \pm 0.6$ & $71.6 \pm 1.2$ \\
\hline $973(700)$ & $53.1 \pm 1.1$ & $53.7 \pm 0.7$ & $52.7 \pm 1.1$ & $48.9 \pm 1.6$ & $50.2 \pm 1.2$ \\
\hline $1023(750)$ & $35.9 \pm 0.6$ & $42.9 \pm 0.3$ & $35.4 \pm 0.9$ & $35.6 \pm 1.0$ & $32.9 \pm 0.8$ \\
\hline $1073(800)$ & $23.3 \pm 0.7$ & $31.1 \pm 0.5$ & $24.6 \pm 0.4$ & $25.8 \pm 0.6$ & $22.5 \pm 0.6$ \\
\hline $1123(850)$ & $17.8 \pm 0.4$ & $19.7 \pm 0.4$ & $17.6 \pm 0.7$ & $18.2 \pm 0.3$ & $16.8 \pm 0.4$ \\
\hline $1173(900)$ & $10.5 \pm 0.2$ & $13.1 \pm 0.2$ & $12.9 \pm 0.2$ & $12.6 \pm 0.3$ & $10.8 \pm 0.1$ \\
\hline
\end{tabular}

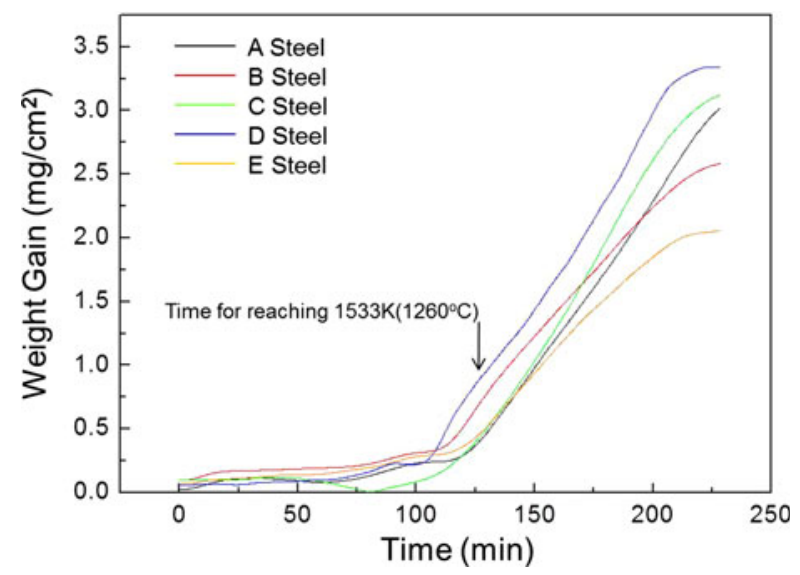

Fig. 2-Weight gain $v s$ time obtained from the TGA test. The arrow indicates the time for reaching $1533 \mathrm{~K}\left(1260{ }^{\circ} \mathrm{C}\right)$.

resulting from the oxidation is not large up to about 130 minutes, after which the test temperature reaches $1533 \mathrm{~K}\left(1260{ }^{\circ} \mathrm{C}\right)$, and then increases abruptly during holding at $1533 \mathrm{~K}\left(1260{ }^{\circ} \mathrm{C}\right)$. After the test, a thick oxide layer is uniformly covered on the specimen surface. The energy-dispersive spectroscopy (EDS) analysis data of this oxide layer shows that the oxide layer mainly comprises $\mathrm{Cr}$ oxides $\left(\mathrm{Cr}_{2} \mathrm{O}_{3}\right) \cdot{ }^{[21,22]} \mathrm{Zr}, \mathrm{Ni}$, and $\mathrm{Cu}$ oxides are not formed on the specimen surface because only small amounts of $\mathrm{Zr}, \mathrm{Ni}$, and $\mathrm{Cu}$ are included in the present ferritic stainless steels. The weight gain and average thickness of the oxide layer were measured, and the results are shown in Table IV.

The weight gain and average thickness are largest in the D steels, and decrease in the order of the C, A, B, and $\mathrm{E}$ steels. The weight gain increases the same way as the average thickness of the oxide layer in all the steels.

\section{Hot-Rolling Test Results}

Plate specimens were sectioned before the hot-rolling test and after each rolling pass, and back-scattered electron images of the surface region were observed as shown in Figures 3 through 7 . The plate surface is covered with an oxide layer, and the average thickness of the layer is measured as shown in Table $\mathrm{V}$.

In the A steel, immediately after the heating furnace (before the hot-rolling test), the surface is uniformly
Table IV. Average Weight Gain and Cr Oxide Layer Thickness of the 21 wt pet Cr-Based Modified STS 430J1L Steels After TGA [Holding Time at $1553 \mathrm{~K}\left(1260^{\circ} \mathrm{C}\right): 90 \mathrm{~min}$ ]

\begin{tabular}{lcc}
\hline Steel & $\begin{array}{c}\text { Weight Gain } \\
\left(\mathrm{mg} / \mathrm{cm}^{2}\right)\end{array}$ & $\begin{array}{c}\text { Thickness of Cr Oxide } \\
\text { Layer }(\mu \mathrm{m})\end{array}$ \\
\hline A & 3.02 & 57.9 \\
B & 2.59 & 49.6 \\
C & 3.12 & 59.8 \\
D & 3.34 & 63.9 \\
E & 2.05 & 39.5 \\
\hline
\end{tabular}

covered with an oxide layer $26-\mu \mathrm{m}$ thick, in which a few pores and cracks are present (Figure 3(a)). According to the EDS analysis of this oxide layer, it consists of $\mathrm{Cr}$ oxides whose composition is similar to that of oxides in the TGA test. After the first pass, the oxide layer remained 17.5- $\mu \mathrm{m}$ thick (Figure 3(b)). However, the oxide layer is broken into large pieces of 3 to $\sim 5 \mu \mathrm{m}$ in size and fine debris because of the reduction by rolls. The thickness of the oxide layer decreases to $10.5 \mu \mathrm{m}$ after the second pass, and the oxide layer mostly consists of fine oxide debris (Figure 3(c)). Some oxide fragments infiltrated the steel surface. The oxide layer is formed on the surface of the B steel before the test, but its thickness is thinner than that of the A steel (Figure 4(a)). Like in the A steel, the oxide layer is fragmented into fine debris, and its thickness decreases as the rolling proceeds (Figures 4(b) and (c)). In the C, D, and E steels, similar processes (i.e., fragmentation of oxide layer into fine debris and reduction of the oxide layer thickness) are observed as shown in Figures 5 through 7 . Because the thickness of the oxide layer formed in the heating furnace is different in each steel, the amounts of oxides fragmented or spalled off from the surface are varied.

When the reduction in oxide layer thickness caused by the simple rolling elongation without spallation of oxides is compared with that caused by the spallation of oxides during the hot-rolling test, the spallation ratio of oxides at each pass can be calculated. The parentheses in Table $\mathrm{V}$ show the thicknesses of the oxide layer theoretically calculated when the simple elongation of the oxide layer is estimated without the oxide spallation from the surface, from which the spallation ratios of oxides are obtained. The thickness of the oxide layer formed in the heating furnace is largest in the D steel, 

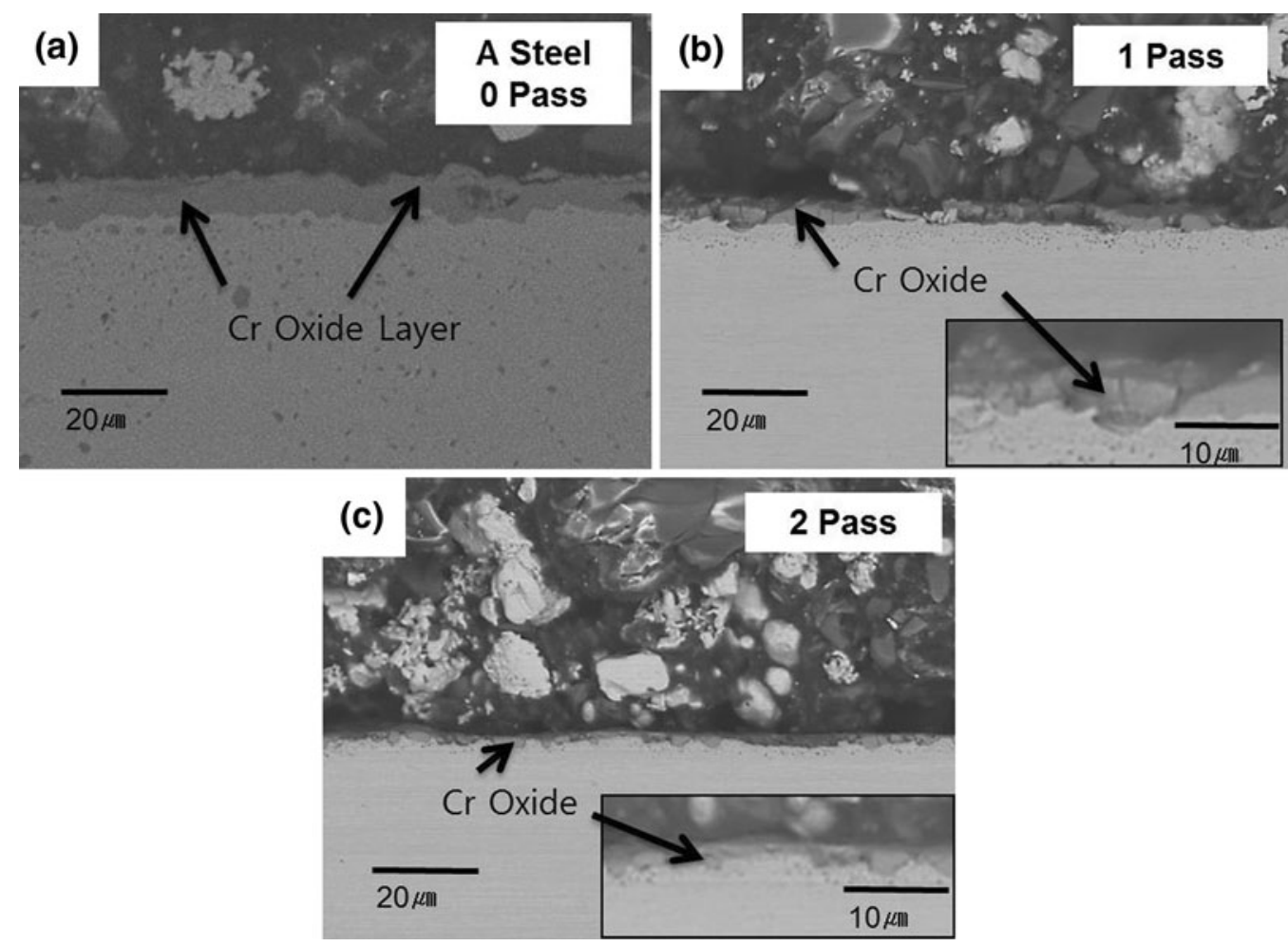

Fig. 3-Back-scattered electron images of the cross section of the A steel plates after $(a)$ 0, (b) 1, and (c) 2 rolling passes, showing Cr oxides. Insets in (b) and (c) are higher-magnification images of the Cr oxide layer.

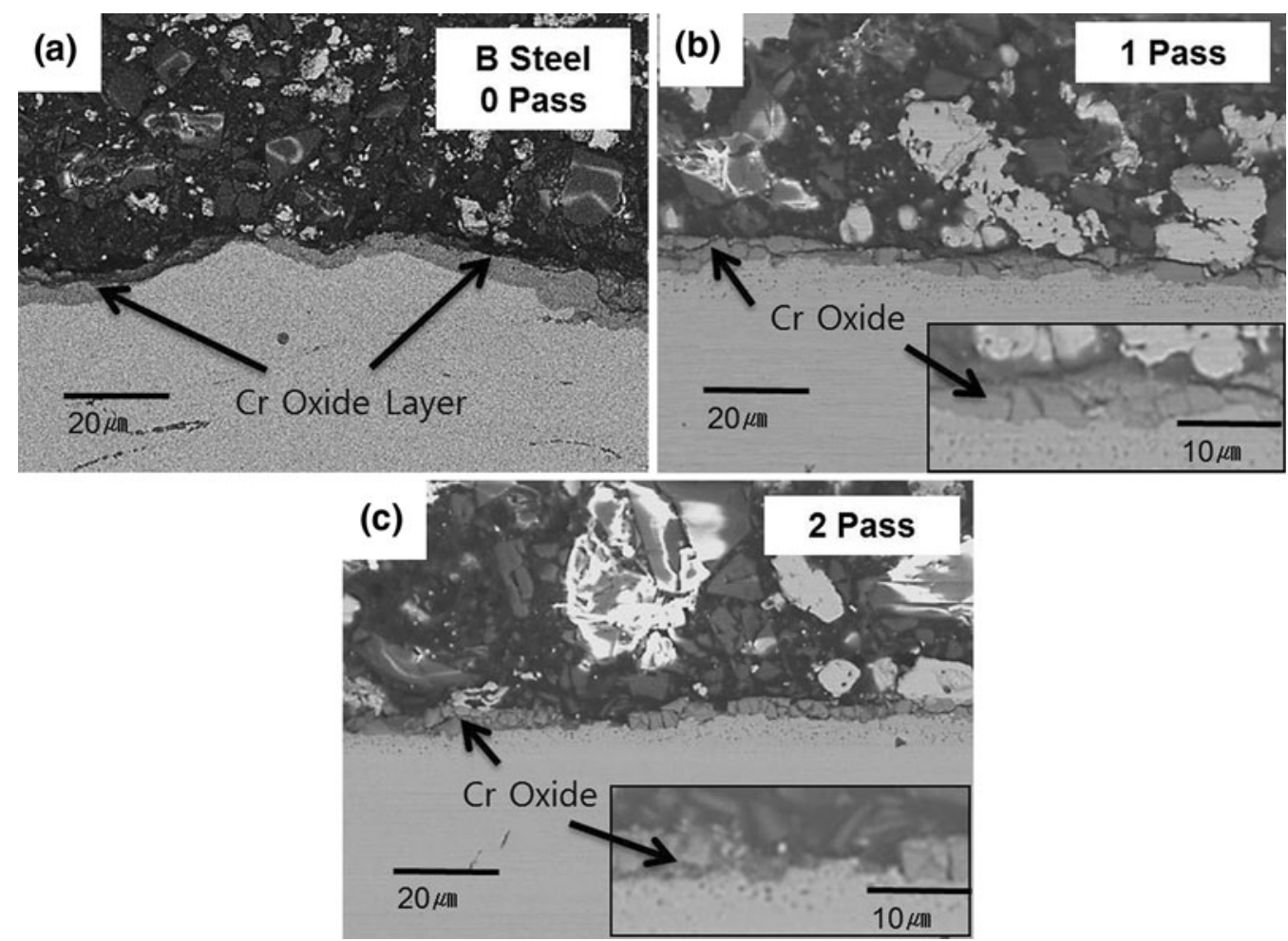

Fig. 4-Back-scattered electron images of the cross section of the B steel plates after $(a) 0,(b) 1$, and $(c) 2$ rolling passes, showing Cr oxides. Insets in (b) and (c) are higher-magnification images of the $\mathrm{Cr}$ oxide layer. 

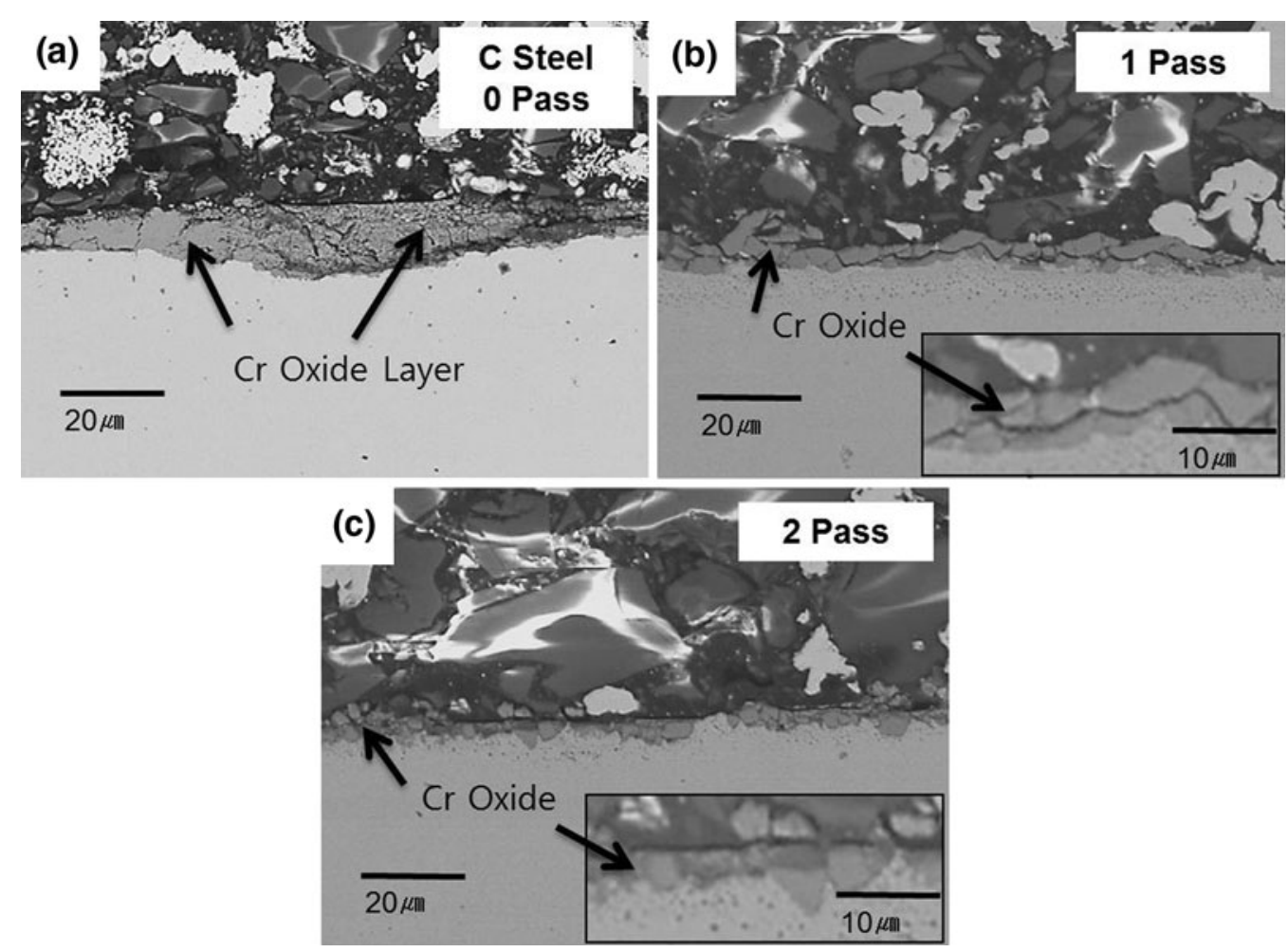

Fig. 5-Back-scattered electron images of the cross section of the $\mathrm{C}$ steel plates after $(a) 0,(b) 1$, and $(c) 2$ rolling passes, showing Cr oxides. Insets in (b) and (c) are higher-magnification images of the $\mathrm{Cr}$ oxide layer.
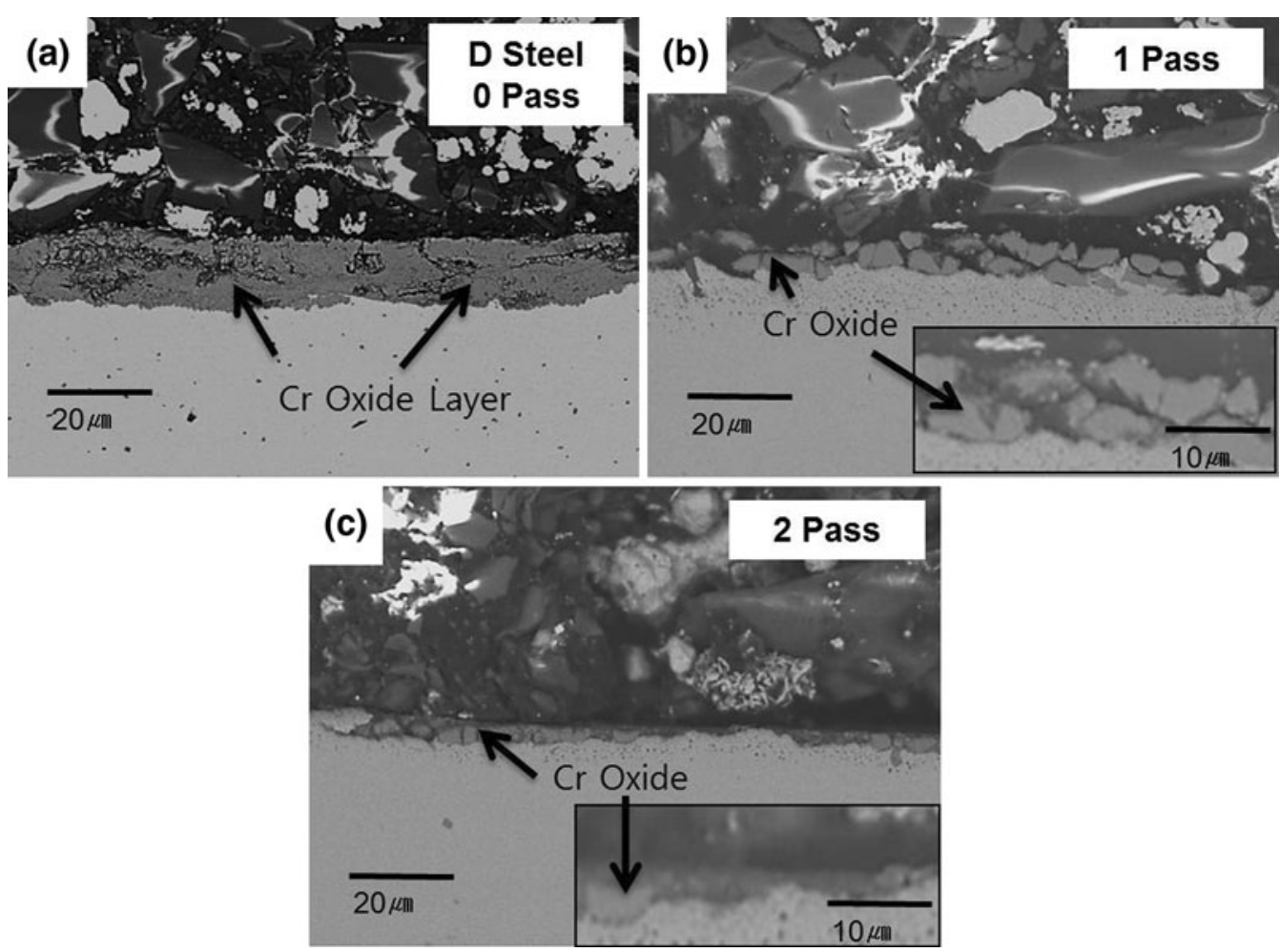

Fig. 6-Back-scattered electron images of the cross section of the D steel plates after $(a) 0,(b) 1$, and (c) 2 rolling passes, showing Cr oxides. Insets in (b) and (c) are higher-magnification images of the $\mathrm{Cr}$ oxide layer. 

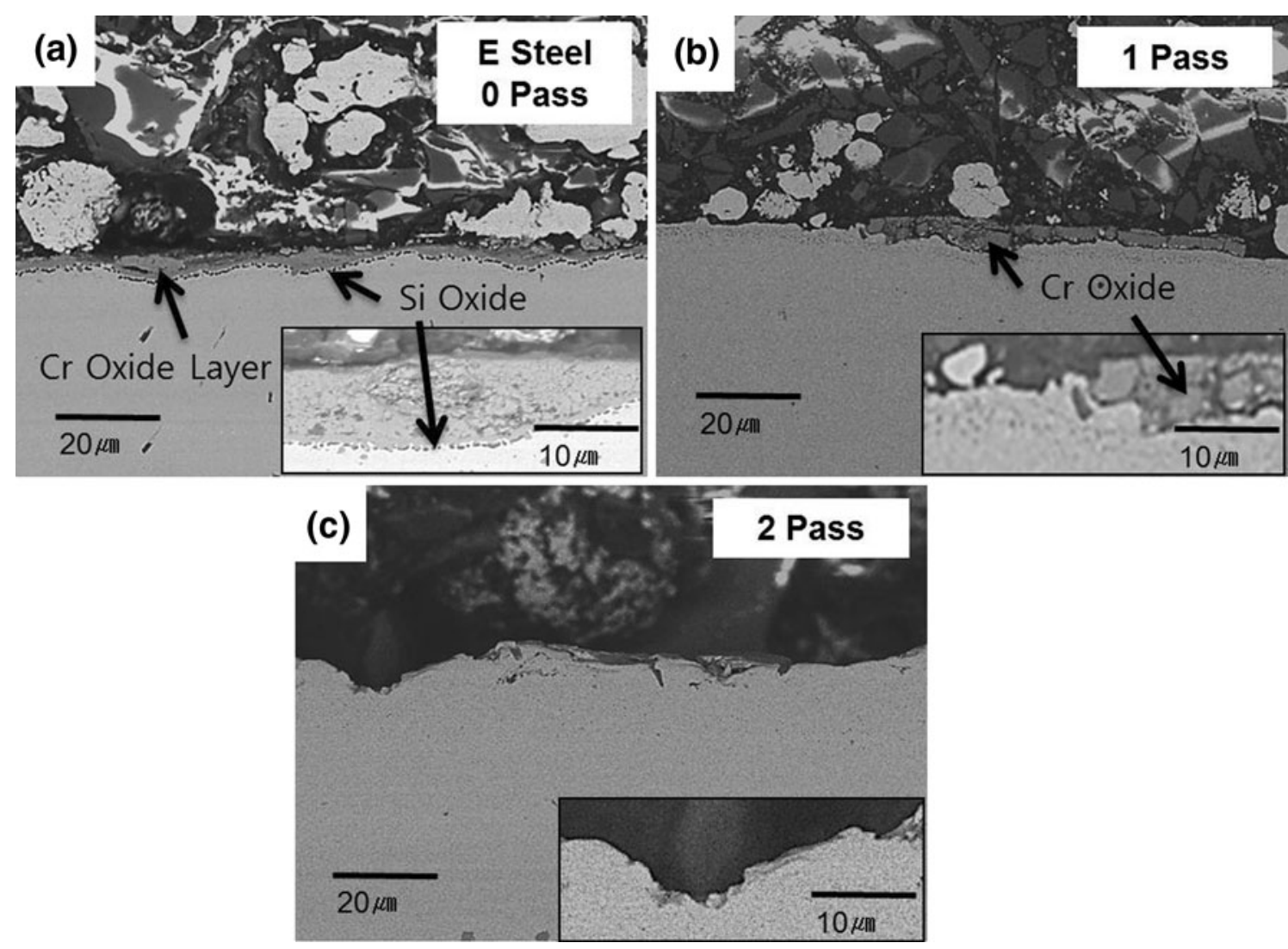

Fig. 7-Back-scattered electron images of the cross section of the E steel plates after $(a) 0,(b) 1$, and $(c) 2$ rolling passes, showing Cr and $\mathrm{Si}$ oxides. Insets in (a) through (c) are higher-magnification images of the $\mathrm{Cr}$ oxide and $\mathrm{Si}$ oxide layers.

Table V. Thickness and Spallation Ratio of the Cr Oxide Layer Formed After the Hot-Rolling Test

\begin{tabular}{lccc}
\hline Steel & $\begin{array}{c}\text { Rolling } \\
\text { Pass }\end{array}$ & $\begin{array}{c}\text { Thickness of Cr } \\
\text { Oxide Layer }(\mu \mathrm{m})\end{array}$ & $\begin{array}{c}\text { Spallation Ratio } \\
\text { of Cr Oxide Layer (Pct) }\end{array}$ \\
\hline A & 0 & 26.3 & - \\
& 1 & $14.8(17.5)^{*}$ & 15.6 \\
B & 2 & $5.3(10.5)^{*}$ & 49.6 \\
& 0 & 21.5 & - \\
& 1 & $12.2(14.3)^{*}$ & 34.9 \\
C & 2 & $5.6(8.6)^{*}$ & - \\
& 0 & 27.2 & 11.2 \\
D & 1 & $16.1(18.1)^{*}$ & - \\
& 2 & $8.2(10.9)^{*}$ & 9.8 \\
E & 0 & 29.1 & - \\
& 1 & $17.5(19.4)^{*}$ & 27.0 \\
& 2 & $8.5(11.6)^{*}$ & 70.5 \\
\hline
\end{tabular}

*Thickness of the $\mathrm{Cr}$ oxide layer theoretically calculated when the simple elongation of the $\mathrm{Cr}$ oxide layer is estimated without the spallation from the surface.

and decreases in the order of the $\mathrm{C}, \mathrm{A}, \mathrm{B}$, and E steels. It is thinner than that of the TGA test (Table IV) because the temperature and holding time are lower and shorter, respectively, in the hot-rolling test. However, the thickness tendency of the oxide layer measured from the rolling test is well matched with that measured from the TGA test.

In the D steel, the thickest oxide layer is formed in the heating furnace, and a considerable amount of oxides remains on the surface even after the second pass. In contrast, the E steel has the thinnest oxide layer in the heating furnace, and the largest spallation of oxides occurs during the rolling passes. For example, the spallation ratio of the second pass reaches 70 pct in the E steel, which leaves parts of the surface region uncovered by oxides (Figures 7(b) and (c)). The oxide layer thickness of the $\mathrm{C}$ steel is thinner than that of the $\mathrm{D}$ steel before and after the rolling test, but is thicker than those of any other steels. The oxide layer thickness existed after the rolling test tends to be proportional to that which existed before the test.

\section{DISCUSSION}

To clarify the mechanisms of sticking, it is necessary to first understand the high-temperature rolling behavior in relation to microstructures including the thickness of the oxide layer formed on the rolled steel surface. ${ }^{[6-12]}$ In the present study, hot-rolling tests were conducted by a pilot-plant-scale rolling machine, and the formation and fragmentation processes of $\mathrm{Cr}$ oxides were studied by steps, from which the amount of sticking was evaluated. 
According to the hot-rolling test results of Figures 3 through 7 and Table $\mathrm{V}$, the oxide layer formed in the heating furnace is not extinguished during hot rolling, but is broken off into pieces or fragments and then remains on the surface with an increasing number of rolling passes. The decarburized layer formed in the furnace before hot rolling of conventional plain carbon steels or high-strength low alloy steels is peeled off by a descaling treatment or mostly extinguished during rough rolling. However, most of the oxide layer formed during heating of stainless steels remains even during hot rolling unless it is artificially peeled off by applying a descaling treatment. Parts of the remaining oxide layer are broken by rolls, but a considerable amount of oxides are distributed on the surface region. The oxides are elongated together with the base steel as the rolling proceeds, and often leave parts of the surface region uncovered by oxides because the amount of oxides is reduced by the elongation. The total reduction ratio in the rolling test of Figures 3 through 7 is 60 pct, and the surface area of the steel after the rolling test increases 2.5 times that before the rolling test. Thus, parts of the thick oxide layer formed on the steel surface before the rolling test are broken off and gone. Some oxides infiltrates the steel, but the surface regions with hardly any oxides can exist as the surface area increases. The hardness of the surface region without oxides is significantly lower than that of the surface region with oxides, and parts of the steel surface can be removed because of the reduction by rolls. ${ }^{[12]}$ Oxides in the surface region contribute to the increased surface hardness and enhance the resistance to sticking. To prevent or minimize sticking in ferritic stainless steels, therefore, it is desirable to promote an oxide layer as thick as possible in the heating furnace and to keep the slab temperature as high as possible, whereas the descaling treatment of the oxide layer should not be applied before the rolling.

Because sticking is significantly affected by the thickness of the oxide layer present on the steel surface, it can be evaluated by the initial thickness of the oxide layer and the amount of the oxide spallation as shown in Table V. The initial thickness of the surface oxide layer formed in the furnace is thickest in the $\mathrm{D}$ steel, and decreases in the order of the C, A, B, and E steels. In the $\mathrm{D}$ steel, the thick surface oxide layer is formed in the heating furnace, and a considerable amount of the layer remains even after the rolling test (Figures 6(a) through (c)). In the other steels, the surface oxide layer thickness decreases with an increasing rolling pass number, but the final thickness of the oxide layer tends to be linearly proportional to the initial thickness of the layer formed before the test. Thus, the amount of sticking can be effectively estimated by measuring and analyzing the oxide layer formed in the heating furnace.

The thickness of the oxide layer measured after the TGA test (Table IV) is proportional to that measured after the hot-rolling test (Table V). This result implies that the TGA test is useful for explaining the formation behavior of the surface oxide layer during hot rolling. Major oxides formed in ferritic stainless steels are $\mathrm{Cr}$ oxides, and their oxidation behavior is related to $\mathrm{Cr}$ activity. ${ }^{[23,24]}$ Oxide-forming metal elements need to satisfy the following equation to form oxides by interacting with oxygen ${ }^{[23]}$.

$$
N_{\mathrm{B}}^{(\mathrm{O})}>\left[\frac{\pi g *}{2 v} N_{\mathrm{O}}^{(\mathrm{S})} \frac{D_{\mathrm{O}} V_{\mathrm{m}}}{D_{\mathrm{B}} V_{\mathrm{OX}}}\right]
$$

where $N_{\mathrm{B}}^{(\mathrm{O})}, N_{\mathrm{O}}^{(\mathrm{S})}, v, D_{\mathrm{O}}, D_{\mathrm{B}}, V_{\mathrm{m}}$, and $V_{\mathrm{OX}}$ are the density of metal, solubility of oxygen in metal, infiltration velocity of oxide layer into metal, diffusion coefficient of oxygen, diffusion coefficient of metal, volume of metal per 1 mole, and volume of oxygen per 1 mole, respectively. According to Eq. [1], the concentration of oxide-forming metal elements decreases when the oxygen flux is prevented or the diffusion of metal elements increases. The $\mathrm{Cr}$ activity favorably affects the value of $D_{\mathrm{B}}$ and consequently the formation of $\mathrm{Cr}$ oxides because the $\mathrm{Cr}$ concentration required for forming $\mathrm{Cr}$ oxides decreases.

Because the $\mathrm{Cr}$ activity is closely related to the amount of oxides formed at high temperatures in ferritic stainless steels, ${ }^{[24]}$ it can be estimated at a given high temperature by thermodynamic calculations. ThermoCalc, ${ }^{[25]}$ which is a commercial thermodynamic calculating program, was used for the calculations, and the upgraded version of TCFE2000 $0^{[26,27]}$ was used for the thermodynamic database. The given temperature is $1533 \mathrm{~K}\left(1260{ }^{\circ} \mathrm{C}\right)$, which is the heating furnace temperature. The $\mathrm{Cr}$ activity is varied with contents of alloying elements of $\mathrm{Zr}, \mathrm{Ni}, \mathrm{Cu}$, and $\mathrm{Si}$, and the results are shown in Figures 8(a) through (d). The Cr activity increases as the contents of $\mathrm{Cu}, \mathrm{Zr}, \mathrm{Ni}$, and $\mathrm{Si}$ increase.

To confirm the correlation between $\mathrm{Cr}$ activity and actual high-temperature oxidation behavior, the $\mathrm{Cr}$ activity data are compared with the TGA test data (Table IV). The effects of alloying element $\mathrm{Cu}$ added to the stainless steels can be analyzed by comparing the B and $\mathrm{C}$ steels. The amount of oxidation as expressed by the weight gain increases in the $\mathrm{C}$ steel containing 0.4 wt pet $\mathrm{Cu}$. As the contents of $\mathrm{Ni}$ and $\mathrm{Zr}$ increase in the C and D steels and in the A and D steels, respectively, the amount of oxidation increases. Thus, the amount of oxidation increases with increasing amounts of $\mathrm{Cu}, \mathrm{Ni}$, and $\mathrm{Zr}$, and is matched with the $\mathrm{Cr}$ activity data. The increment of $\mathrm{Si}$ in the $\mathrm{A}$ and $\mathrm{E}$ steels reduces the amount of oxidation, which shows the opposite result of $\mathrm{Cr}$ activity and oxidation behavior. This result might be associated with another factor in the peculiar oxide formation behavior of $\mathrm{Si}$. Thus, the effects of the Si addition on high-temperature oxidation and sticking should be analyzed in detail.

Figures 9(a) and (b) show the EDS data of the oxide layer formed after TGA of the A and E steels. In the E steel, spherical $\mathrm{Si}$ oxides $\left(\mathrm{SiO}_{2}\right)$ are continuously formed along the interfacial area between the $\mathrm{Cr}$ oxide layer and the base steel (Figure 9(b)), whereas only Cr oxides are found above the base steel in the A steel (Figure 9(a)). The mapping data of $\mathrm{Si}$ and $\mathrm{O}$ confirm the formation of Si oxides along the interfacial area. This result indicates that $\mathrm{Si}$ oxides formed along the interfacial area can prevent the movement of $\mathrm{Cr}$ ions and consequently the growth of the $\mathrm{Cr}$ oxide layer. In addition, $\mathrm{Si}$ can act as an oxygen attractor, decrease the reaction of $\mathrm{Cr}$ and 


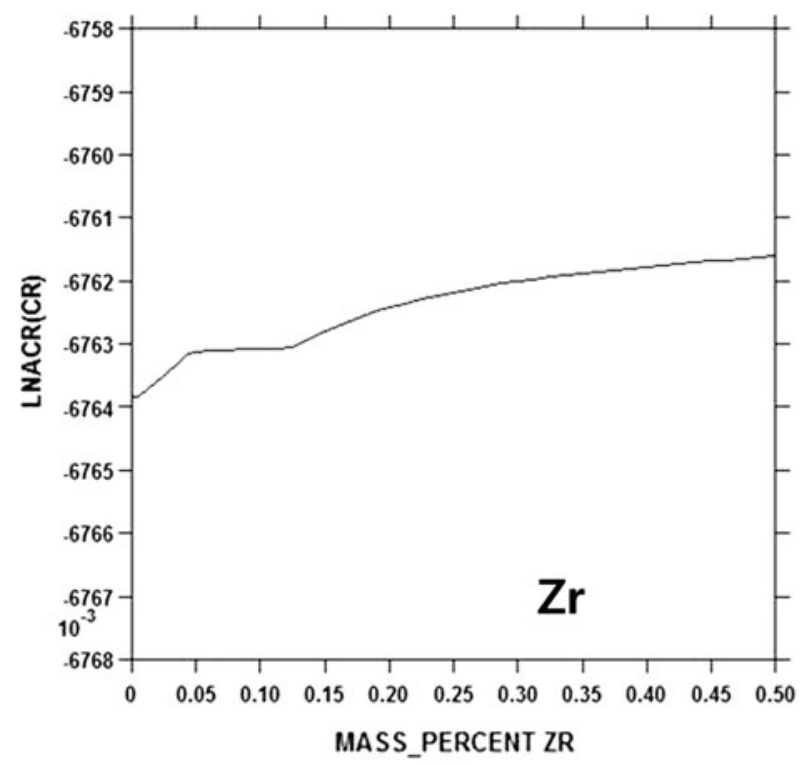

(a)

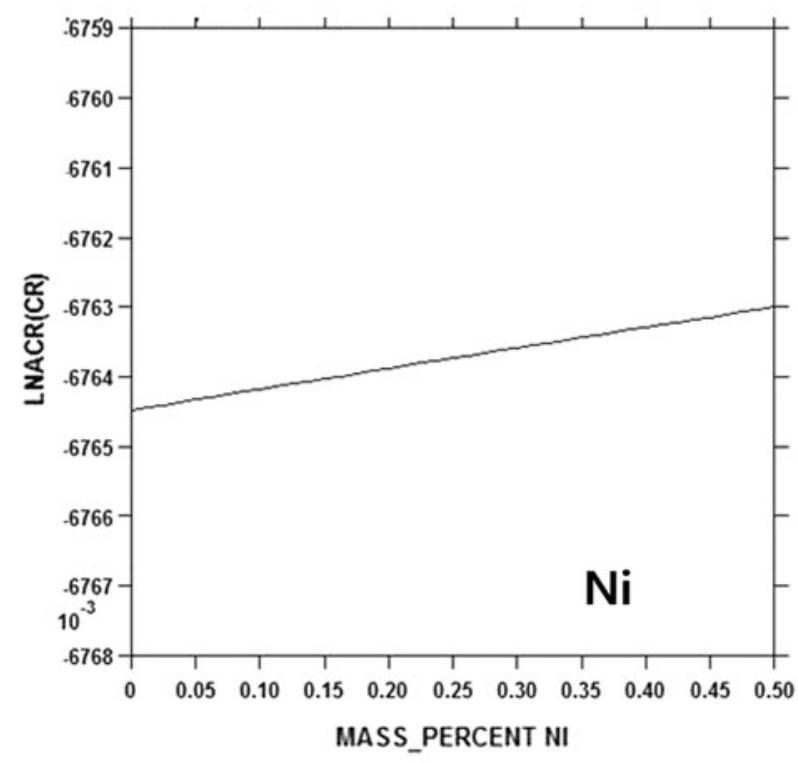

(c)

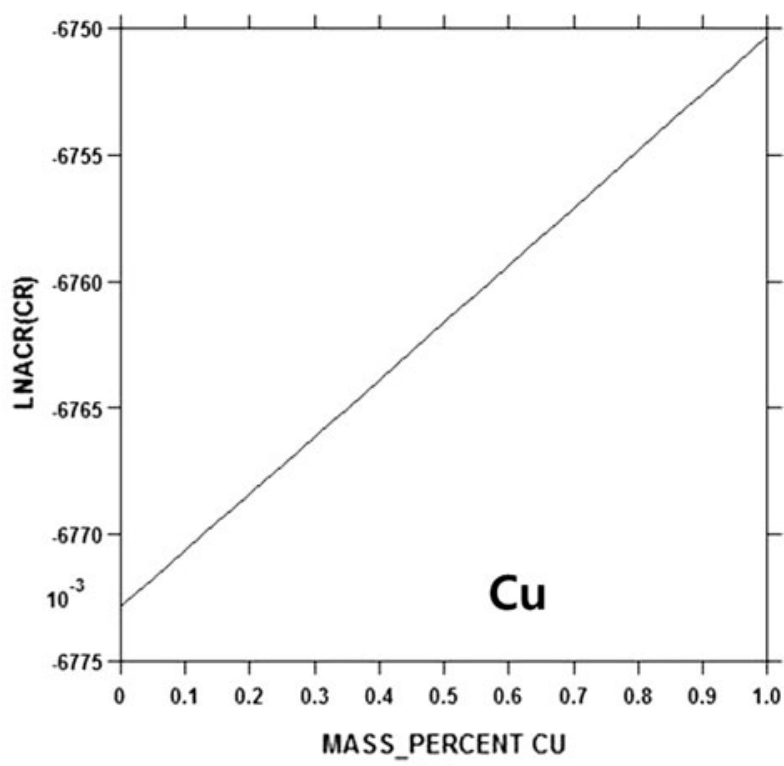

(b)

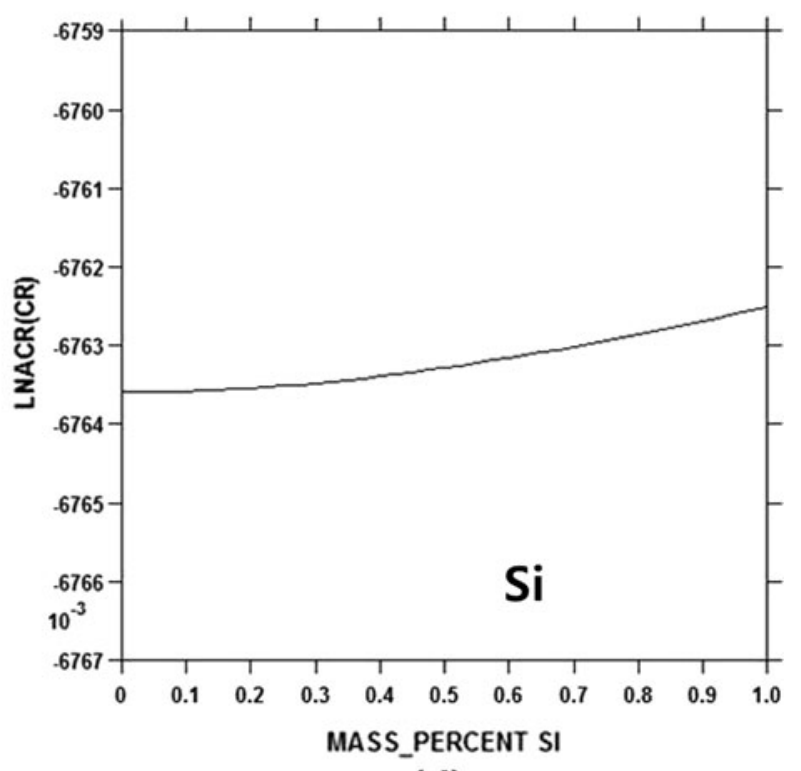

(d)

Fig. 8 - $\mathrm{Cr}$ activity (log scale) vs content of alloying elements of $(a) \mathrm{Zr},(b) \mathrm{Cu},(c) \mathrm{Ni}$, and $(d) \mathrm{Si}$. These $\mathrm{Cr}$ activity data were calculated by an analysis program of ThermoCalc ${ }^{[25]}$ based on TCFE2000. ${ }^{[26,27]}$

oxygen present in the base steel, and reduce the growth of the $\mathrm{Cr}$ oxide layer.

The formation processes of $\mathrm{Si}$ oxides along the interfacial area and the growth of the $\mathrm{Cr}$ oxide layer are illustrated in Figure 10. Si has a strong affinity to oxygen to form $\mathrm{Si}$ oxides, and $\mathrm{Si}$ oxides influence the formation of $\mathrm{Cr}$ oxides. ${ }^{[24,28-30]}$ In the initial oxidation stage, $\mathrm{Si}$ interacts with oxygen to form $\mathrm{Si}$ oxides containing a small amount of $\mathrm{Fe}$ and $\mathrm{Cr}$. These oxides act as nucleation sites for $\mathrm{Cr}$ oxides, and help the $\mathrm{Cr}$ oxide layer to grow rapidly. ${ }^{[28]}$ As the oxidation proceeds, $\mathrm{Si}$ oxides, which are more stable at high temperatures than $\mathrm{Cr}$ oxides, are grown beneath the $\mathrm{Cr}$ oxide layer. Because the oxidation rate of the $\mathrm{Cr}$ oxide layer is determined by the diffusion of $\mathrm{Cr}$ ions through $\mathrm{Si}$ oxides, the formation and growth of $\mathrm{Si}$ oxides reduce the growth rate of the $\mathrm{Cr}$ oxide layer. In other words, the growth of the $\mathrm{Cr}$ oxide layer decreases because the diffusion of $\mathrm{Cr}$ ions is interrupted by $\mathrm{Si}$ oxides. Although the increment of $\mathrm{Si}$ content increases the $\mathrm{Cr}$ activity (Figure $8(\mathrm{~d})$ ), Si readily forms $\mathrm{Si}$ oxides, and $\mathrm{Si}$ oxides are grown beneath the $\mathrm{Cr}$ oxide layer. This process results in the formation of a thin $\mathrm{Cr}$ oxide layer on the steel surface as shown in Tables IV and V.

The adhesive force between the oxide layer and the base steel was measured in the A and E steels by using an adhesion tester (Sebastian Five A; Quad Group, Spokane, WA). After an aluminum stud (cross-sectional 

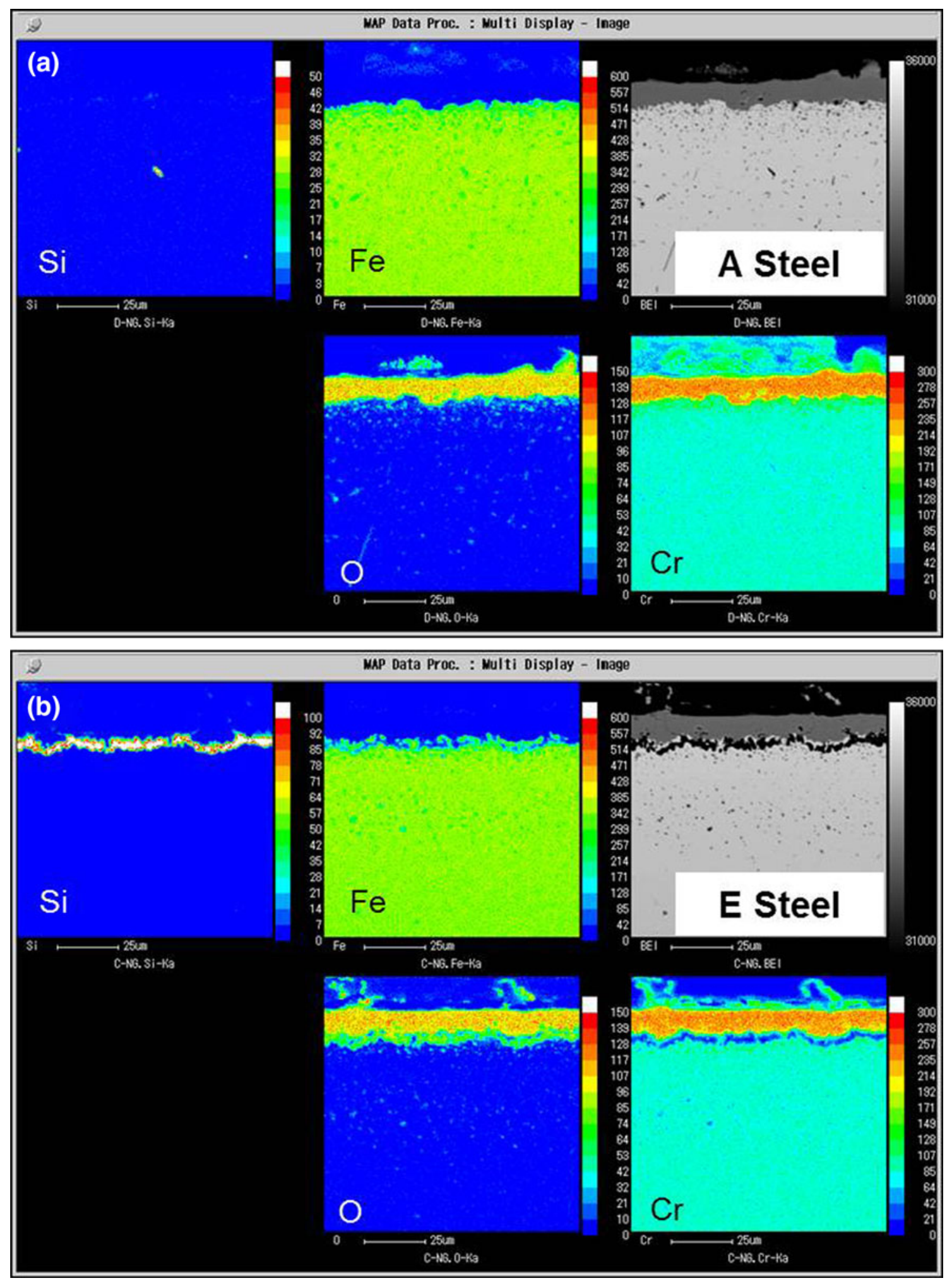

Fig. 9-EDS mapping data of the oxide layer formed after the TGA test of the (a) A and (b) E steels.

area $3 \mathrm{~mm}^{2}$ ) was bonded to the surface oxide layer by epoxy adhesives, the oxide layer was separated from the base steel by pulling the aluminum stud. When the separation occurred, the load was measured and averaged after the three-time tests. The adhesive strengths are 10.6 MPa and 4.22 MPa in the A and E steels, respectively. After the oxide layer was separated, the remaining base steel was sectioned, and the crosssectional area was observed by an SEM as shown in Figures 11(a) through (d). In the A steel, the surface of 

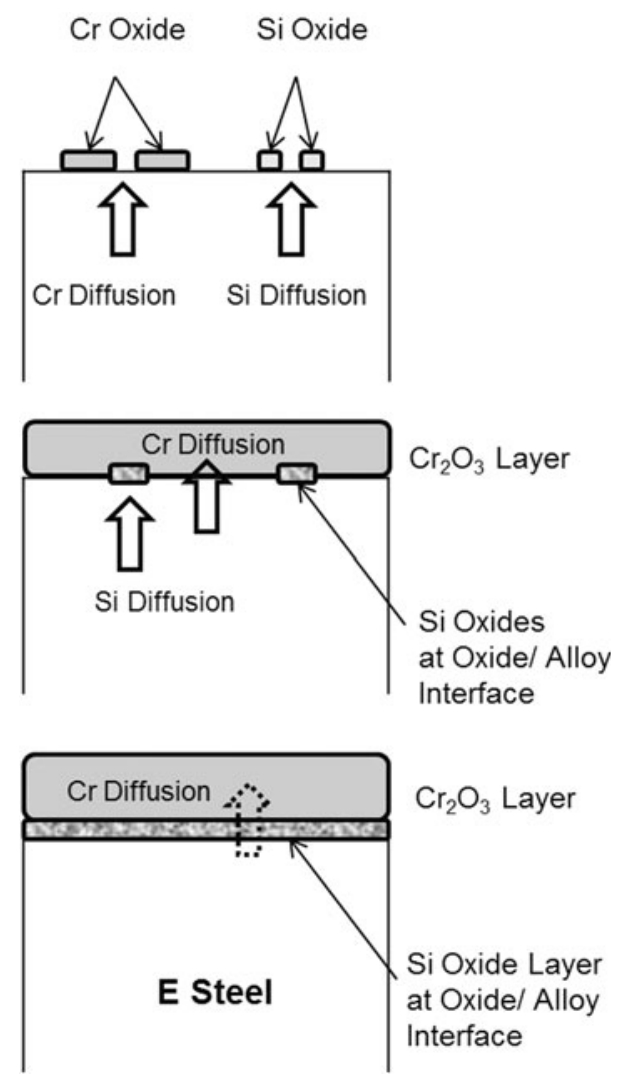

Fig. 10-Schematic illustration showing the formation and growth of $\mathrm{Cr}$ oxides $\left(\mathrm{Cr}_{2} \mathrm{O}_{3}\right)$ and $\mathrm{Si}$ oxides $\left(\mathrm{SiO}_{2}\right)$ in the $\mathrm{E}$ steel.

the base steel is exposed as the $\mathrm{Cr}$ oxide layer is removed from the surface (Figures 11(a) and (b)). In the E steel, however, $\mathrm{Si}$ oxides are retained in the base steel because the interface between the $\mathrm{Si}$ oxides and the $\mathrm{Cr}$ oxide layer is separated and the $\mathrm{Cr}$ oxide layer is spalled out (Figures 11(c) and (d)). This finding implies that the adhesive strength between the Si oxides and the $\mathrm{Cr}$ oxide layer in the $\mathrm{E}$ steel is much lower than the adhesive strength between the $\mathrm{Cr}$ oxide layer and the base steel in the A steel. These adhesive test results agree well with the results of Bamba et al., ${ }^{[19]}$ in which the adhesive force between the $\mathrm{Cr}$ oxide layer and the base steel decreased as the $\mathrm{Si}$ content increased in $\mathrm{Fe}-15 \mathrm{Cr}$ steels. Thus, the $\mathrm{Cr}$ oxide layer is thinly formed in the $\mathrm{E}$ steel, and the $\mathrm{Cr}$ oxide layer is readily spalled off from the surface during the rolling test (see the spallation ratio data in Table $\mathrm{V}$ ) because of the bad adhesive strength between the $\mathrm{Cr}$ oxide layer and the base steel.

As mentioned earlier, the high-temperature oxidation behavior, $\mathrm{Cr}$ activity calculation, and hot-rolling process were investigated on five different kinds of stainless steels with varying contents of $\mathrm{Zr}, \mathrm{Ni}, \mathrm{Cu}$, and $\mathrm{Si}$, from which the effects of alloying elements on sticking are summarized as follows:

(a) Effect of $\mathrm{Zr}$ addition: The effects of alloying element $\mathrm{Zr}$ added to the stainless steels can be analyzed by comparing the A and D steels. As shown in Table $\mathrm{V}$, the $\mathrm{D}$ steel with a small addition of $\mathrm{Zr}$ shows a thicker oxide layer than the A steel. In the two steels, the spallation of oxides occurs as the rolling passes proceed, but the oxide layer formed before and after the rolling test is thicker in the D steel. When considering the beneficial effect of a thick oxide layer on sticking, $\mathrm{Zr}$ has a good effect on reducing sticking even though a small amount (0.02 wt pct) was added to the D steel.

(b) Effect of $\mathrm{Cu}$ addition: By comparing the $\mathrm{B}$ and $\mathrm{C}$ steels of Table I, the effects of 0.4 wt pet $\mathrm{Cu}$ addition is investigated. According to the hot-rolling test results, the oxide layer is thicker in the $\mathrm{C}$ steel than in the B steel. After the second pass, the oxide layer remains uniform on the surface of the $\mathrm{C}$ steel, whereas it remains thin in the B steel. This implies that the $\mathrm{Cu}$ addition positively affects the reduction in sticking.

(c) Effect of $\mathrm{Ni}$ addition: The effect of $\mathrm{Ni}$ addition can be evaluated by comparing the $\mathrm{C}$ and $\mathrm{D}$ steels. After the first pass, the oxide layer is thicker in the $\mathrm{D}$ steel than in the $\mathrm{C}$ steel, whereas the spallation ratio is lower. After the second pass, the oxide layer thickness of the $\mathrm{D}$ steel is similar to that of the $\mathrm{C}$ steel as the spallation takes place more in the D steel, and finely fragmented oxides are uniformly distributed on the surface in both steels. Although oxides are formed more often in the D steel in the heating furnace, the amount of oxides remained after the second pass is similar in both steels, as oxides are broken and spalled off from the surface. Thus, the Ni addition favorably influences the reduction in sticking, but its effect is not large.

(d) Effect of Si addition: To investigate the effect of $\mathrm{Si}$ addition on sticking, the $\mathrm{A}$ and $\mathrm{E}$ steels should be compared. The TGA and hot-rolling results indicate that the oxide layer is thinner in the $\mathrm{E}$ steel containing $0.5 \mathrm{wt}$ pct $\mathrm{Si}$ than in the A steel. As mentioned earlier, in the $\mathrm{E}$ steel, $\mathrm{Si}$ oxides are formed along the interfacial area between the $\mathrm{Cr}$ oxide layer and the base steel, and prevent the formation and growth of the $\mathrm{Cr}$ oxide layer. In addition, as shown in the adhesive test results (Figures 11(a) through (d)), the formation of $\mathrm{Si}$ oxides deteriorates the bonding of the $\mathrm{Cr}$ oxide layer and the base steel, and readily leads to the spallation of $\mathrm{Cr}$ oxides during hot rolling. Because the hardness of the surface region without oxides is significantly lower than that of the surface region with oxides, parts of the rolled steel can be broken off by the rolls. The $\mathrm{Si}$ addition plays a role in increasing sticking, and thus, the reduction in $\mathrm{Si}$ content is desirable for preventing sticking.

Because the rolling test using a pilot-plant-scale rolling machine is a good way to identify sticking phenomenon occurring in actual hot-rolling stands, it can be useful to understand mechanisms of sticking and to suggest desirable alloy-designing conditions for preventing or minimizing sticking. The resistance to sticking is enhanced by adding $\mathrm{Zr}, \mathrm{Cu}$, and $\mathrm{Ni}$ to ferritic stainless steels because these elements help the thick 

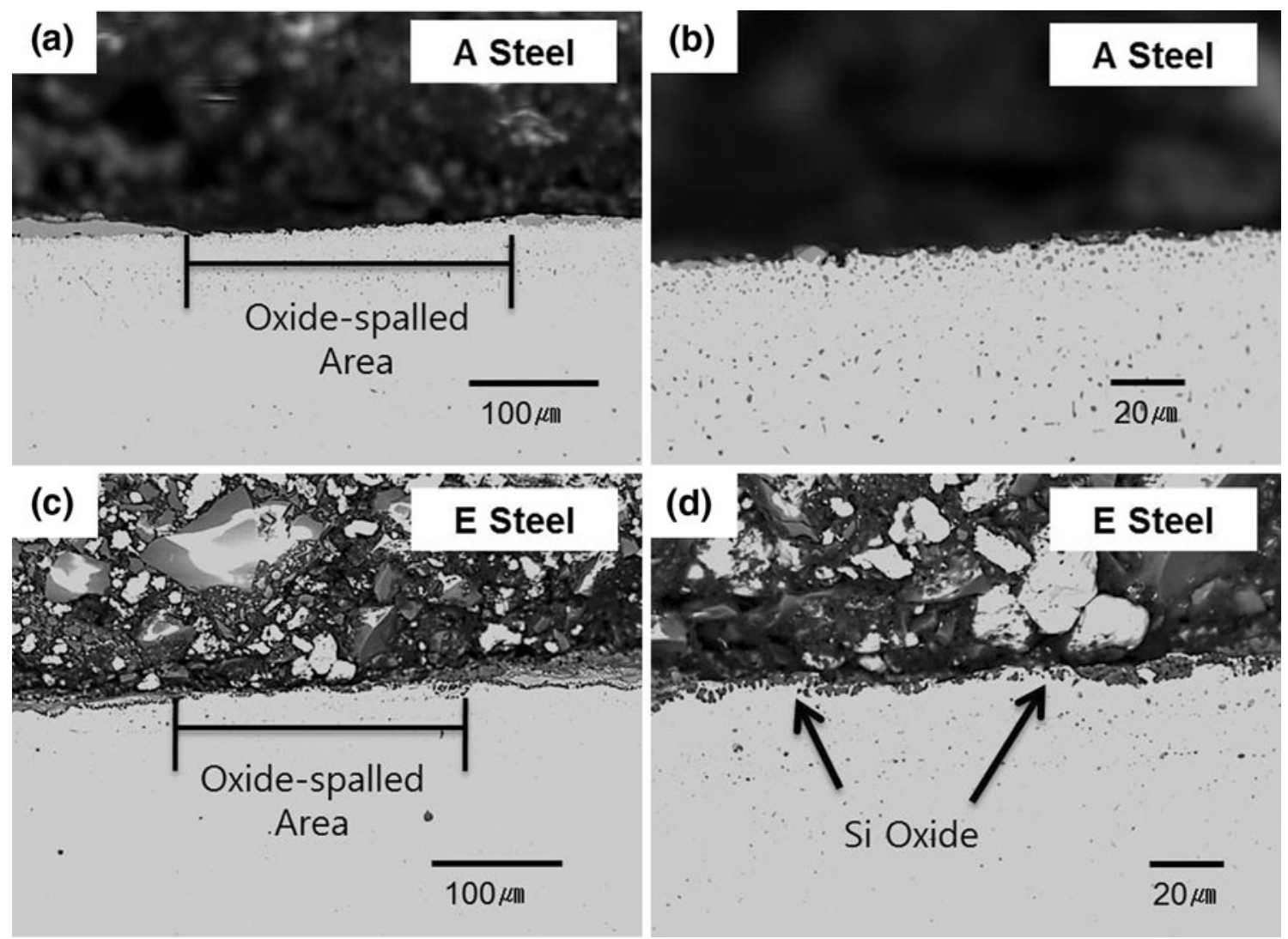

Fig. 11-Back-scattered electron images of the cross section of the $(a)$ and $(b)$ A and $(c)$ and $(d)$ E steel plates after the adhesion test of the Cr oxide layer. (b) and (d) are high-magnification images of the oxide-spalled area in (a) and (c), respectively.

oxide layer to form on the surface of the rolled steel, whereas the $\mathrm{Si}$ addition shows the opposite effect on sticking resistance. Thus, sticking can be reduced by the appropriate alloy designing, from which the oxide layer formed thick in a reheating furnace should not be readily spalled off.

\section{CONCLUSIONS}

In the present study, mechanisms of sticking occurring during hot rolling of modified STS430J1L ferritic stainless steels were investigated, and the effects of alloying elements on sticking were analyzed by the hightemperature oxidation behavior.

1. The formation behavior of high-temperature oxides was investigated by the TGA test in relation to the $\mathrm{Cr}$ activity. The oxide layer mainly consisted of $\mathrm{Cr}$ oxides, and was thickest in the steel containing $\mathrm{Ni}$, $\mathrm{Cu}$, and $\mathrm{Zr}$. The thickness results of the $\mathrm{Cr}$ oxide layer measured after the TGA test was linearly proportional to those measured after the hot-rolling test, and was also matched well with the $\mathrm{Cr}$ activity data except in the Si-rich steel.

2. According to the hot-rolling test results, the $\mathrm{Cr}$ oxide layer formed in the heating furnace was broken off and infiltrated the steel, thereby forming $\mathrm{Cr}$ oxides on the rolled steel surface. Because the surface region without oxides underwent a reduction in hardness rather than the surface region with oxides, the thickness of the surface oxide layer favorably affected the resistance to sticking.

3. The hot-rolling results of the ferritic stainless steels with varying additions of $\mathrm{Zr}, \mathrm{Cu}, \mathrm{Ni}$, and $\mathrm{Si}$ revealed that the addition of $\mathrm{Zr}, \mathrm{Cu}$, and Ni worked favorably for decreased sticking, but the Si addition negatively affected the resistance to sticking. In the Si-rich steel, Si oxides were continuously formed along the interfacial area between the $\mathrm{Cr}$ oxide layer and the base steel, and interrupted the formation and growth of the $\mathrm{Cr}$ oxide layer. The $\mathrm{Si}$ addition played a role in increasing sticking, and thus, the reduction in Si content was desirable for preventing sticking.

\section{ACKNOWLEDGMENTS}

This work was supported by POSCO under a contract No. PD-06903. The authors would like to thank Drs. Yong Deuk Lee and Kwang Tae Kim of POSCO for their help in the hot-rolling test.

\section{REFERENCES}

1. O. Kato and T. Kawanami: J. Jpn. Soc. Tech. Plast., 1987, vol. 28, pp. 264-71.

2. O. Kato and T. Kawanami: J. Jpn. Soc. Tech. Plast., 1989, vol. 30, pp. 103-09. 
3. O. Kato, S. Uchida, and T. Kimuma: Seitetsu Kenkyu, 1989, vol. 335 , pp. $35-42$.

4. T. Nakanishi: J. Soc. Tribol. Lubr. Eng., 1993, vol. 49, pp. 365-70.

5. S. Uchida, H. Yamamoto, M. Akata, K. Watanabe, and O. Kato: What's New in Roll Technologies of the World, Report of Research Committee on Rolling Roll, ISIJ, Tokyo, Japan, 1995, p. 183.

6. W. Jin, J.Y. Choi, and Y.Y. Lee: ISIJ Int., 1998, vol. 38, pp. 739 43.

7. W. Jin, J.Y. Choi, and Y.Y. Lee: ISIJ Int., 2000, vol. 40, pp. 789 93

8. J.K. Kim, S.G. Hong, K.B. Kang, and C.Y. Kang: Met. Mater. Int., 2009, vol. 15, pp. 843-49.

9. D.-C. Wen: Met. Mater. Int., 2009, vol. 15, pp. 365-72.

10. S. Lee, D. Suh, S. Oh, and W. Jin: Metall. Mater. Trans. A, 1998, vol. 29A, pp. 696-702.

11. C.-Y. Son, C.K. Kim, D.J. Ha, S. Lee, J.S. Lee, K.T. Kim, and Y.D. Lee: Metall. Mater. Trans. A, 2007, vol. 38A, pp. 2776-87.

12. D.J. Ha, Y.J. Kim, J.S. Lee, Y.D. Lee, and S. Lee: Metall. Mater. Trans. A, 2009, vol. 40A, pp. 1080-89.

13. S. Kim, S. Lee, K. Han, S. Hong, and C. Lee: Met. Mater. Int., 2010, vol. 16 , pp. 483-88.

14. D.-C. Wen: Met. Mater. Int., 2010, vol. 16, pp. 13-19.

15. J.L. Cavazos: Mater. Charact., 2006, vol. 56, pp. 96-101.

16. E.E. Oguzie, J. Li, Y. Liu, D. Chen, Y. Li, K. Yang, and F. Wang: Electrochim. Acta, 2010, vol. 55, pp. 5028-35.

17. M. Vardavoulias and G. Papadimitriou: Mater. Lett., 1996, vol. 27 , pp. $349-53$.
18. S.-T. Kim and Y.-S. Park: Met. Mater. Int., 2009, vol. 15, pp. 22130.

19. G. Bamba, Y. Wouters, A. Galerie, F. Charlot, and A. Dellali: Acta Mater., 2006, vol. 54, pp. 3917-22.

20. D.J. Ha, H.K. Sung, S. Lee, J.S. Lee, and Y.D. Lee: Mater. Sci. Eng. A, 2009, vol. A507, pp. 66-73.

21. H.E. Kadiri, R. Molins, Y. Bienvenu, and M.F. Horstemeyer: Oxidation Metals, 2005, vol. 64, pp. 63-97.

22. H.E. Kadiri, R. Molins, Y. Bienvenu, and M.F. Horstemeyer: Oxidation Metals, 2005, vol. 64, pp. 99-117.

23. N. Birks and G.H. Meier: Introduction of High Temperature Oxidation of Metals, Edward Arnold, London, UK, 1983, p. 80.

24. H.G. Jung, J.K. Ahn, and K.Y. Kim: J. Kor. Inst. Met. Mater., 2001, vol. 39, pp. 1032-40.

25. B. Sundman, B. Jansson, and J.-O. Andersson: CALPHAD, 1985, vol. 9, pp. 153-90.

26. B.-J. Lee and B. Sundman: TCFE2000: The Thermo-Calc Steels Database, KTH, Stockholm, Sweden, 1999, pp. 2-81.

27. K.G. Chin, H.J. Lee, J.H. Kwak, J.Y. Kang, and B.J. Lee: J. Alloys Compd., 2010, vol. 505, pp. 217-23.

28. F.H. Stott and F.I. Wei: Oxidation Metals, 1989, vol. 31, pp. 36975.

29. O. Kubashewski and B.E. Hopkins: Oxidation of Metals and Alloys, Butterworths Scientific Publications, London, UK, 1962, p. 173.

30. F. Velasco, A. Bautista, and A. Gonzalez-Centeno: Corr. Sci., 2009, vol. 51, pp. 21-27. 